\title{
The Effect of Value Creation on Student Satisfaction in Higher Education Institutions in Lebanon
}

\author{
Pierre Al-Khoury $^{1 *}$, Anis Khatib ${ }^{2}$ \\ ${ }^{1}$ Pierre Al-Khoury, PhD. Vice President for Development and Dean of the Faculty of Business and Insurance, \\ Lebanese German University, Lebanon \\ ${ }^{2}$ Anis Khatib, PhD. Professor of Accounting and Auditing, Head of Anti Money Laundering Dept.- Middle East \\ Airlines, Lebanon
}

*Corresponding Author: Pierre Al-Khoury, Vice President for Development and Dean of the Faculty of Business and Insurance, Lebanese German University, Lebanon

\begin{abstract}
The purpose of the study is to check the effect of value creation on student satisfaction at universities in Lebanon. The paper used the questionnaire to cater the level of satisfaction in universities. The correlation was measured to see the positive relationship between the value creation and student's satisfaction. The results shows that the most important aspects were those associated with teaching and learning, while the least important were those associated with the physical facilities. This study helps to improve the policies of Lebanese university to enhance the value creation and to attract more students.
\end{abstract}

Keywords: Value Creation, Student's Satisfaction, Higher Education, Lebanon

\section{INTRODUCTION}

The educational institutions are considered as learning environments where two ways of communication and learning occurred. This active interaction can be positive or lead to less advantageous depending on multiple factors. The physical factors vary effecting level of satisfaction of the students. In countries where education is the integral part of socio-economic structures, level of satisfaction is crucial for achievements. From the kinder gardens till the higher education fierce competitions propels the authorities to create value for their own sustainability in the market.

Value creations from the aspect of students are getting importance day by day. It is considered worthwhile and their opinion is collected by questionnaire to express their satisfaction level as feedback.

In Lebanon and many other European countries (Crawford, 1991) students are considered as primary customers in the universities to deliver higher education. The path of delivery of education comprises of direct recipients (students) without any mediators. At the end of their degree, feedback is collected which represent value creation and helps in image building of university. Image has a robust impact on the retention of current students and the attraction of potential students (James et al, 1999).

Dissatisfaction leads to low retention rate of students in the university which will adversely affect the funding and profitability of universities(Rowley, 2003). The objective of the study is to measure the satisfaction level of students by judging multiple factors that can incorporate in increasing or decreasing value creation.

\section{LITERATURE REVIEW}

State of satisfaction gained when individual goes through the process of certain actions and as an outcome the required expectations are fulfilled ( Kotler and Clarke, 1987). Student satisfaction is achieved when perceived performances are match with the expectations. In universities where students come with certain high expectation the level of satisfaction is also difficult to determined (Palacio, Meneses and Perez, 2002). There is no model for measuring student's satisfaction. The contradiction is customer satisfaction models are used to determine the students level of satisfaction (Hom, 2002). In universities where students are considered as customers, because they are the fee 
payers and as a result can demand their point of view to be considered (William, 2002). Different universities are performing customer relationship management strategies (Levitt, 1960) whereby they observe the behaviour of students, examine their expectations and try to adjust to their behaviour and examination (Venoos and Madadiyekta 2005). This process allows universities to identify which students are satisfied depending on their initial expectation, and increase the desired student segment.

Satisfaction leads to happy outcome. Cropanzano and Wright (2001)examined that "happy people notice opportunities; unhappy person is less likely to take risks when something precious is in short supply. Butcher, George, \& Link, (1993) has suggested that life satisfaction represents an overall attitude, composed of components of satisfaction in various domains of life". Multiple factors affect the level of value creation (Gunawardena and Zittle, 1997).Instructors also may play a modest role in class design and flexibility, much of the influence potential rests with administrators and students themselves. The satisfaction can be enhanced by offering flexible course and making availability of instructor with technical support and advance technological course contents (Watson and Michaelsen, 1988). The technique of elaborating the contents also depends on teacher.

The concept of value creation has not only affected the business world but also the educational institutions around the globe. From the kinder gardens till the higher education fierce competitions propels the authorities to create value for their own sustainability in the market.

The concept of value creation in students were mentioned by Japanese educator and philosopher TsunesaburoMakiguchi (1871-1944). "The enduring happiness earned from the education and university. Considering the lifelong happiness of learners to be the authentic goal of education, he structured his educational philosophy and efforts toward developing the value-creating potentialities of students".(Gebert and Joffee, 2007)

\section{Methodology of STUdy}

The primary method of data collection was applied to measure the satisfaction against the services provided. The more the satisfied students more value will be created. The questionnaire is consist of two parts. First one deals with the demographics and the second one is various categories services provided. SPSS was used to analyse the answers and interpret the correlations.

\section{RESUltS AND ANALYSIS}

The reliability of the scale was evaluated using Cronbach's alpha coefficient, with a coefficient of $88 \%$. After determining the validity and reliability of the scales, the questionnaires were distributed to participants who are the students of the 5 major universities in Lebanon selected on the basis of maximum students.

The majority of the respondents to the survey were males with a percentage equal to $55 \%$, and the percentage of females is equal to $45 \%$. The respondents that were aged less than 18 , had a percentage of $11.3 \% .31 .8 \%$ were aged between 18 and $22.39 .1 \%$ were aged between 23 and $27.17 .9 \%$ were aged 28 or more. $66.9 \%$ of the respondents had a bachelor degree. $13.2 \%$ of them had master's degree and 19.9 had other than these two degrees. The study shows that the majority of our respondents with a percentage of $60.9 \%$ agreed that the level of life satisfaction affects the student performance in the classroom.

$72.8 \%$ is the percentage of the respondents who agreed with that the group examination produce positive outcomes, which is the same opinion as Reinig, Horowitz and Whittenburg (2012). The majority of the respondents with a percentage of $47 \%$ agreed with this statement, and $39.7 \%$ of them strongly agreed, so these two are high percentages.

According to the results $57 \%$ of the respondents agreed that a workload have an impact on student satisfaction in a negative way if it's too demanding.

\section{Correlations}

Correlations were created among different variables and the numbers are analyzed below.

- Males tend to believe that E learning could enhance student's success and satisfaction more than females, because there's a positive correlation between these two variables $\left(0.187^{*}\right)$.

- We realize that the adults believe that the group examination produce positive outcomes (reduce anxiety, improve cognitive processing...) 0.199*, they also tend to believe that the course instructors, have the ability to influence students experiences and satisfaction $\left(0.164^{*}\right)$, 
and finally with that the universities are measured not just by their majors but also by the quality of campus services $\left(0.166^{*}\right)$, the age is positively correlated with these 3 sayings.

- The level of education is positively correlated with that the universities are measured not just by their majors but also by the quality of campus services $\left(0.170^{*}\right)$ which means that students who have masters degree believe that the quality of campus services plays a major role in measuring universities.

- The students studying in private schools are with the saying that says, universities are measured not just by their majors but also by the quality of campus services. They are positively correlated $(0.180 *)$.

- The students who agree that the level of life satisfaction affects the student performance in the classroom believe that universities should maintain a healthy relationship with the parents by organizing regular meetings with parents to discuss their concerns $(0.162 *)$, and that personal values play a major role when it comes to students' loyalty and satisfaction in high education $\left(0.161^{*}\right)$, and finally they tend to believe that the community effect of the university affects students' satisfaction and thus performance $\left(0.187^{*}\right)$. This analysis was done because these statements are positively correlated.

- There's a positive correlation between that the group examination produce positive outcomes and with that universities should adopt effective customer relationship management strategies to achieve student satisfaction $\left(0.168^{*}\right)$ and, which means that the students who agree with the use of group examination are with the adaptation of CRM.

- The students, who agree that course instructors, have the ability to influence students' experiences and satisfaction tends to the statement that says: a workload that is perceived as too demanding can have a negative impact on student satisfaction $(0.178 *)$. They are positively correlated.

- A workload that is perceived as too demanding, can have a negative impact on student satisfaction is positively correlated with the availability of services at a level that exceeds students 'expectations in order to avoid financial implications $\left(0.177^{*}\right)$ and also with that the personal values play a major role when it comes to students' loyalty and satisfaction in high education $\left(0.163^{*}\right)$, which means that the students who agree with the workload statement believe that the services should be available at a level that exceeds expectations, and they believe in the major role that personal values play in students' satisfaction.-

- The students, who agree with that the recreational facilities create more loyalty to the universities, tend to believe in the sustainability of a uniform standard of service performance in order to increase students' loyalty. They are positively correlated $(0.204 *)$.

- The students who agree that universities are measured just by their majors but also by the quality of campus services believe that universities should sustain a uniform standard of service performance in order to increase students' loyalty $\left(0.191^{*}\right)$, and that the personal values play a major role when it comes to students' loyalty and satisfaction in high education $\left(0.199^{*}\right)$, and finally agree with the statement that says that E learning could enhance students' success and satisfaction $\left(0.205^{*}\right)$. These 3 statements are positively correlated with the measurement of universities by their quality of campus services.

- Universities should provide services at a level that exceeds students' expectations in order to avoid financial implications is positively correlated with the statement that says that the $\mathrm{E}$ learning could enhance students' success and satisfaction $\left(0.166^{*}\right)$, which means that the students who agree with the availability of services believe that $E$ learning is very important in students' success and satisfaction.

- Universities should maintain a healthy relationship with the parents by organizing regular meetings with parents to discuss their concerns is positively correlated with that the community effect of the university affects students' satisfaction and thus performance $\left(0.180^{*}\right)$, it means that students who agree with the healthy relationship with parents believe in the community effect.

- And finally we see a positive correlation between that the universities should sustain a uniform standard of service performance in order to increase students' loyalty and that the 
personal values play a major role when it comes to students' loyalty and satisfaction in high education $\left(0.172^{*}\right)$ table no.1. So the students, who agree with the importance of a uniform standard of service performance, believe that personal values play a major role in students' loyalty and satisfaction.

Table1

\begin{tabular}{|l|l|}
\hline \multicolumn{1}{|c|}{ Variable } & Mean \\
\hline Universities are measured not just by their majors but also by the quality of campus service. & 3.28 \\
\hline Course instructors have the ability to influence students' experience and satisfaction. & 3.21 \\
\hline $\begin{array}{l}\text { Universities should adopt effective customer relationship management strategies to achieve } \\
\text { student satisfaction. }\end{array}$ & 3.05 \\
\hline E-learning could enhance student's success and satisfaction. & 3.05 \\
\hline $\begin{array}{l}\text { Universities should provide services at a level that exceeds student's expectations in order to } \\
\text { avoid financial implications. }\end{array}$ & 3.05 \\
\hline $\begin{array}{l}\text { Group examination produces positive outcomes. (reduces anxiety, improve cognitive } \\
\text { processing...etc.) }\end{array}$ & 3.03 \\
\hline Recreational facilities create more loyalty to the university. & 3.03 \\
\hline The community effect of the university affects student's satisfaction and thus their performance. & 3.00 \\
\hline Personal values play a major role when it comes to students' loyalty and satisfaction in high education & 2.97 \\
\hline A workload that is perceived as too demanding can have a negative impact on students'satisfaction. & 2.93 \\
\hline $\begin{array}{l}\text { Universities should sustain a uniform standard of service performance In order to increase } \\
\text { student's loyalty. }\end{array}$ & 2.83 \\
\hline $\begin{array}{l}\text { Universities should maintain a healthy relationship with parents by organizing regular meetings } \\
\text { with them to discuss certain concerns. }\end{array}$ & 2.58 \\
\hline The level of life satisfaction affects the student performance in the classroom. & 2.57 \\
\hline
\end{tabular}

\section{CONCLUSION}

As a conclusion, after finishing the study and analysing the results, more concepts about the satisfaction factors that affect university students nowadays were detected. The quality of campus, course instructors, effective customer relationship management, E-learning, services availability, group examination, recreational facilities, and the community effect are all important factors in increasing students 'satisfaction and performance, so universities and students should focus on them to reach their desire.

\section{LIMITATIONS}

Although the research has reached its aims, there were some unavoidable limitations. First because of the time limit, this research was conducted only a small size of population. Therefore, to generalize the results for larger groups, the study should have involved more participants maybe from different cities and ages, we tried to reach more regions and students attending more universities but this didn't fully succeed. Second, the access to people was a little difficult because not all the people who receive the survey responded. Third, the study was only in Lebanese society, that's why it was only the opinion of some Lebanese respondent, and for sure the opinion will be different in other societies, but because of out limited resources we couldn't expand it.

\section{RECOMMENDATIONS FOR FUTURE RESEARCH}

It's recommended that such a study should be addressed to a larger population including, more age groups and clear differentiation between public and private universities. If the resources exist the try to expand more globally is a must and the study could be more interested.

\section{REFERENCES}

[1] Brief, A. P., Butcher, A. H., George, J. M., \& Link, K. E. (1993). Integrating bottom-up and top-down theories of subjective well-being: the case of health. Journal of personality and social psychology, 64(4), 646.

[2] Crawford, F. (1991), Total Quality Management, Committee of Vice-Chancellors and Principals, occasional paper (London, December), cited in Hill, F.M. (1995), "Managing service quality in higher education: the role of the student as primary consumer", Quality Assurance in Education, Vol. 3 No. 3, pp. 10-21

[3] Cropanzano, R., \& Wright, T. A. 2001. When a "happy" worker is really a "productive" worker-A review and further refinement of the happy productive worker thesis. Consulting Psychology Journal: Practice and Research, 53: 182-197. 
[4] Gebert, A., \&Joffee, M. (2007). Value creation as the aim of education: Tsunesaburo Makiguchi and Soka education. Ethical visions of education: Philosophies in practice, 65-82.

[5] Gunawardena, C. N., \&Zittle, F. (1997). Social presence as a predictor of satisfaction within a computer mediated conferencing environment. American Journal of Distance Education, 11(3), 8-25.

[6] Hom, W. (2002). Applying Customer Satisfaction Theory to Community College Planning of of Student Services. Journal. Retrieved January 7th 2004, from http://www.ijournal.us/issue_02/ij_issue02Willard Hom_01.htm

[7] James, D.L., Baldwin, G. and McInnis, C. (1999), Which University? The Factors Influencing the Choices of Prospective Undergraduates, Centre for the Study of Higher Education.

[8] Kotler, P., and Clarke, R.N. (1987) Marketing for Health Organization.

[9] Levitt, T. (1960) Marketing myopia. Harvard business review, 38(4),24-47.

[10] Melbourne.Makiguchi and Soka education. Ethical visions of education: Philosophies in practice, 65-82.

[11] Palacio, A., DíazMeneses, G., \& Pérez Pérez, P. J. (2002). The configuration of the university image and its relationship with the satisfaction of students. Journal of Educational administration, 40(5), 486-505.

[12] Reinig, B. A., Horowitz, I. and Whittenburg, G. E. (2012). Does attitude towards one's group impact student performance in a team-exam environment? A longitudinal analysis, International Journal of Applied Decision Sciences, 5(1), 77-96.

[13] Rowley, J. (2003b), "Designing student feedback questionnaires”, Quality Assurance in Education, Vol. 11 No. 3, pp. 142-9.

[14] Venoos, D., \&Madadiyekta, S. (2005). The Study of Factors Affecting Customer...... Satisfaction with Internal Flights of IRI Airline (Homa). Administrative Sciences.

[15] Watson, W. E. and Michaelsen, L. K. (1988) Group interaction behaviors that affect group performance on an intellective task, Group \& Organization Studies, 13(4), pp. 495-516.

[16] William, J. (2002). The student satisfaction approach: student feedback and its potential role in quality assessment and enhancement. 24th EAIR Forum, Prague, 8-11 September.

\section{QUESTIONNAIRE}

- Age, gender, type of school,

- Group examination

- Level of life satisfaction

- Course instructors, have the ability to influence

- a workload have an impact on student satisfaction in a negative way if it's too demanding

- Recreational facilities create more loyalty to the university

- Universities are measured not just by their majors but also by the quality of campus services

- Universities should adopt effective customer relationship management strategies to achieve students' satisfaction

- Universities should maintain a healthy relationship with the parents by organizing regular meeting with parents to discuss their concerns.

- - Universities should sustain a uniform standard of service performance in order to increase students loyalty.

- Personal values play a major role when it comes to students loyalty and satisfaction in high education.

- The community effect of the university affects students satisfaction and thus performance.

- E learning could enhance students success and satisfaction

\section{AUTHOR'S BIOGRAPHY}

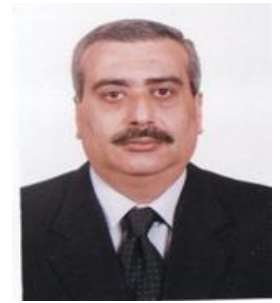

Anis N. El Khatib, He holds a $\mathrm{PhD}$ in International Business Managementspecialization in Finance from the International School of Management (ISM). Currently, he is the Head of Anti-Money Laundering Compliance Department at the Middle East Airlines (MEA).He has 23 years of teaching experience (full timer) at the Lebanese American University (LAU), and the Hariri Canadian University (HCU). El Khatib Anis has 20 years of field experience as internal and 
external auditor for several reputable companies and banks in Lebanon. He has also worked as a financial consultant for companies in different fields. He is a member in the Lebanese Association of Certified Public Accountants (LACPA) and a sworn accountant at Lebanese Courts. El Khatib has several technical and academic papers and project in the areas of his expertise.

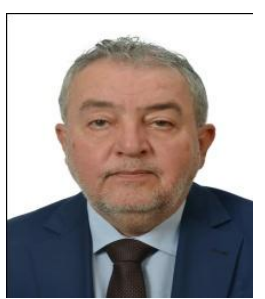

Pierre Al-Khoury PhD, A PhD (Business Administration), Masters in Money \& Banking (Financial Economics) - MMB with more than 3 decades of experience in administrative functions, education management, research \& development, business generation, financial and management consultancy amongst others across diverse organizational domains like banking, finance, public sector, trade and consultancy. Distinguished researcher and publisher of more than 30 scientific papers in international referred journals and 4 books primarily focused on knowledge management. Presently functioning as Vice President for Development (Academic Provost Functions included) with Lebanese German University, LGU.

Citation: Pierre Al-Khouryl, Anis Khatib" “ "The Effect of Value Creation on Student Satisfaction in Higher Education Institutions in Lebanon" International Journal of Managerial Studies and Research (IJMSR), vol 6, no. 6, 2018, pp. 16-21. doi:http://dx.doi.org/10.20431/2349-0349.0606003.

Copyright: (C) 2018 Authors. This is an open-access article distributed under the terms of the Creative Commons Attribution License, which permits unrestricted use, distribution, and reproduction in any medium, provided the original author and source are credited. 